\title{
Molecular Markers for Tm-2 Alleles of Tomato Mosaic Virus Resistance in Tomato
}

\author{
Ainong Shi ${ }^{1,2 *}$, Richard Vierling ${ }^{2,6}$, Richard Grazzini ${ }^{3}$, Pengyin Chen ${ }^{4}$, Homer Caton $^{1}$, Dilip Panthee ${ }^{5}$ \\ ${ }^{1}$ Syngenta Seeds, Slater, USA; ${ }^{2}$ Indiana Crop Improvement Association and Department of Agronomy, Purdue University, West \\ Lafayette, USA; ${ }^{3}$ GardenGenetics LLC, Bellefonte, USA; ${ }^{4}$ Department of Crop, Soil, and Environmental Sciences, University of \\ Arkansas, Fayetteville, USA; ${ }^{5}$ Department of Horticultural Science, North Carolina State University, Mountain Horticultural Crops \\ Research and Extension Center, Raleigh, USA; National Corn Growers Association, Cepi Drive Chesterfield, USA; ${ }^{6}$ National Corn \\ Growers Association, Chesterfield, USA. \\ Email: ${ }^{*}$ ainong.shi@syngenta.com, ainong_shi@hotmail.com
}

Received January $23^{\text {rd }}, 2011$; revised March $26^{\text {th }}, 2011$; accepted March $31^{\text {st }}, 2011$.

\begin{abstract}
Tomato mosaic virus (ToMV) is one of the most infectious virus diseases in tomato (Solanum lycopersicum L). The practical and effective method of controlling this disease is through genetic control by using major resistance genes. So far, three genes Tm-1, Tm-2 and Tm- $2^{2}$ conferring resistance to ToMV have been reported and utilized in tomato cultivar development. Marker assisted selection (MAS) has become very important and useful tool in selection of ToMV resistant tomato lines or hybrids. The objective of this research was to identify allele-specific PCR-based, cleaved amplified polymorphic sequence (CAPS), and allele-derived single nucleotide polymorphism (SNP) markers for Tm-2 loci. Four allele-specific PCR-based markers were identified: one for Tm-2, one for Tm- $2^{2}$, and two for the susceptible allele tm-2. Three allele-derived CAPS markers were identified, which can identify and distinguish three alleles, tm-2, Tm-2 and $\mathrm{Tm}-\mathrm{2}^{2}$ in tomato germplasm. Three SNP markers were developed specific for Tm-2 locus. These markers will provide breeders with a tool in selection of Tm-2 and Tm-2 ${ }^{2}$ resistance genes in tomato breeding program.
\end{abstract}

Keywords: Cleaved Amplified Polymorphic Sequence, Marker-Assisted Selection, Single Nucleotide Polymorphism, Solanum Lycopersicum, Tomato, Tomato Mosaic Virus (ToMV), Tm-2

\section{Introduction}

Tomato mosaic virus (ToMV) is one of the most infectious virus diseases in tomato (Solanum lycopersicum L. formerly, Lycopersicon esculentum Mill). The practical and effective method of controlling this disease is through introducing major resistance gene(s). So far, three genes, $T m-1, T m-2$ and $T m-2^{2}$ of ToMV resistance have been reported and used in tomato cultivar development [1-5]. The Tm-1 gene was introgressed into S. lycopersicum from the wild tomato species $S$. habrochaites and mapped to chromosome 5 and it conferred resistance to ToMV strains 0 and $2[1,4,6,7]$. The $T m-1$ gene has been cloned and the sequences were stored in GenBank with five accessions DJ344478 to DJ344481, and DJ344505. The other two genes $\mathrm{Tm}-2$ and $\mathrm{Tm}-\mathrm{2}^{2}$ were introgressed from S. peruvianum and were located closely to the centromere of chromosome 9 and are considered to be allelic and Tm-2 conferred resistance to ToMV strains 0 and 1 , whereas allele $\mathrm{Tm}-2^{2}$ conferred resistance to
ToMV strains 0,1 and $2[2,3,5,8-10]$.

Molecular markers have been widely used in genetic mapping and marker-assisted selection (MAS) for disease resistance in tomato [6]. For Tm-2 genes of ToMV resistance, Ohmori et al. [11] reported 13 random amplified polymorphic DNA (RAPD) markers linked to the Tm-2 locus. From the 13 RAPD markers, Motoyoshi et al. [11] found two markers, OPE16 (900) and OPN31 (1000), nearest to the Tm-2 locus. Six out of the 13 RAPD markers distributed within $0.7 \mathrm{cM}$ on chromosome 9 were cloned and sequenced to be converted into sequence characterized amplified region (SCAR) markers [11]. Sobir et al. [12] and Dax et al. [13] identified co-dominant SCAR markers tightly linked to $T m-2^{2}$. Three alleles, $T m-2, T m-2^{2}$, and $t m-2$ at $T m-2$ locus have been cloned and sequenced (GenBank Accessions: AF536199, AF536200, and AF536201) and three cleaved amplified polymorphic sequences (CAPS) markers were developed to distinguish the three alleles in tomato [14]. Based on the two CAPS markers reported by Lanfemeijer et al. 
[14], Arens et al. [15] developed a co-dominant assay combining tetra primers designed from the SNP regions of the two CAPS markers using a method called ARMS-PCR SNP and this Tetra-primer ARMS-PCR assays can amplify PCR products with different DNA fragment sizes from tomato lines carrying $\mathrm{Tm}-2$ or $\mathrm{Tm}-\mathrm{2}^{2}$, and susceptible allele $t m-2$.

Single nucleotide polymorphism (SNP) is becoming to be the most useful as molecular marker in genome mapping, association studies, diversity analysis, and tagging genes for economically important traits in crop plants because of their abundance and automated highthroughput genotyping [16-18]. SNPs have been discovered and verified in tomato [19-22] and successfully used in selecting resistance to bacterial speck and bacterial spot in tomato [22,23]. The objective of this research was to identify Tm-2 allele-specific PCR-based markers, CAPS markers, and SNP markers for MAS in tomato breeding.

\section{Materials and Methods}

\subsection{Plant Materials}

Twenty-three tomato genotypes including released or commercial cultivars and accessions were used in this research (Table 1). Seeds of 15 tomato accessions (LA series) were obtained from the C.M. Rick Tomato Genetics Resource Center, Dept. of Plant Sciences, University of California, Davis, CA 95616 (http://tgrc.ucdavis.edu), six cultivars were purchased from commercial sources, and two lines NY07-461 and NY07-464 were obtained from Cornell University; refined selections from a cross between "Brandywine" and "Rose de Berne" (received as NY07-461 (Brandyrose \#1) and NY07-464 (Brandyrose \#2)). Among the 23 genotypes, three cultivars, Royal Red (LA2088), CLN2264F (LA4285), and LA3433 are homozygous for Tm-2 (Tm-2/Tm-2); Mogeor (LA3471), Sophya, and VFNT Cherry (LA1221) are homozygous for $T m-2^{2}\left(T m-2^{2} / T m-2^{2}\right)$; Swt Cluster, Bush Celebrity, and Golden Girl are heterozygous for $\mathrm{Tm}-2^{2}\left(\mathrm{Tm}-2^{2} / \mathrm{tm}-2\right)$; and the other 14 genotypes contained the susceptible allele tm-2 (Table 1).

\subsection{DNA Extraction, PCR Amplification and DNA Sequencing}

Genomic DNA was extracted from fresh leaves of greenhouse-grown plants using the CTAB (Cetyltrimethylammonium Bromide) method [24,25]. The gene- specific primers for Tm-2, Tm- $2^{2}$, or tm-2 at Tm-2 locus were designed from the sequences of the GenBank accessions AF536199, AF536200, and AF536201 using the primer design tool-Primer-BLAST (http://www.ncbi. nlm.nih.gov/tools/primer-blast/index.cgi?LINK_LOC=B1 astHome). AF536199 is the accession in GenBank that contains the sequence of the tm-2 susceptible allele; AF536200 is the sequence $T m-2$ resistance allele; and AF536201 is the sequence of $T m-2^{2}$ resistance allele. The size of the AF536199 sequence of the allele tm-2 is 2820 bp; AF536200 is 2819 bp; and AF536201 is 9837 bp [3]. Primers Tm2RS-f2, Tm2RS-r2, Tm2RS-f3, and Tm2RSr3 were designed for the three sequences of AF536199, AF536200, and AF536201; Tm2S-f1, Tm2S-r1, Tm2S-f2, and Tm2S-r2 for AF536199 only; Tm2R-f1c and Tm2Rr4 for both AF536200 and AF536201; Tm2R-r3 for AF536200 only; and Tm2aR-r3 for AF536201 only (Table 2).

PCR amplification was performed in an eppendorf thermal cycler (Eppendorf, Westbury, NY) following standard PCR procedures with minor modifications. Briefly, each $50 \mu \mathrm{l}$ PCR reaction mixture consisted of $29.8 \mu \mathrm{l}$ sterilized $\mathrm{ddH}_{2} \mathrm{O}, 10 \mu \mathrm{l} 5 \mathrm{x}$ Mango Taq reaction buffer (Bioline, London, UK), $3 \mu \mathrm{MgCl}_{2}(25 \mathrm{mM}), 1.5$ $\mu \mathrm{l}$ dNTP (2.5 mM each), $1.5 \mu \mathrm{l}$ each primer $(5 \mu \mathrm{M}), 0.2$ $\mu l$ Mango Taq DNA polymerase (5 U/ $\mu \mathrm{l})$ (Bioline, London, UK), and $2.5 \mu \mathrm{l}$ template DNA (30 ng/ $\mu \mathrm{l})$. For the primer pairs, Tm2RS-f2/r2 and Tm2RS-f3/r3, PCR procedure consisted of an initial denaturation step of $94^{\circ} \mathrm{C}$ for $4 \mathrm{~min}$ followed by 36 to 38 cycles of 15 to 30 second at $94^{\circ} \mathrm{C}$ for denaturation, 15 to $30 \mathrm{~s}$ at 51 to $56^{\circ} \mathrm{C}$ for annealing, and 40 to $75 \mathrm{~s}$ at $72^{\circ} \mathrm{C}$ for extension depending on primer pairs with a final extension step at $72^{\circ} \mathrm{C}$ for 5 min (Table 3). The PCR fragments were separated by gel electrophoresis with $1.5 \%$ agarose gel in $0.5 \mathrm{X}$ TAE buffer, stained with ethidium bromide, and visualized with UV light.

The PCR fragments were sequenced in the Purdue Genomics Core Facility, Purdue University, West Lafayette, IN 47907. Before sequencing of PCR products, PCR products were purified using QIA quick PCR Purification Kit (Qiagen Inc, Valencia, CA) following the manufacturer's instructions of the protocol. The sequences amplified from the two primer pairs Tm2RS-f2/-r2 and Tm2RSf3/-r3 in tomato were submitted to GenBank using a DNA sequence submission and update tool-Sequin (http://www.ncbi.nlm.nih.gov/Sequin/).

\subsection{SNP Identification and Genotyping}

SNP discovery was postulated from available Tm-2 sequences of AF536199, AF536200, and AF536201. The multiple sequence alignment showed that 68 SNPs and one InDel were observed among the three sequences. One of the approaches to SNP validation is through re-sequencing of the same gene among various genotypes. Two Tm-2 gene-specific primer pairs Tm-2RS-f2/r2 and Tm-2RS-f3/r3 were designed from the sequences of AF536199, AF536200, and AF536201 using PrimerBLAST (Table 2) and used to run PCR among tomato 
Table 1. Allele-specific PCR-based, allele-derived CAPS, and allele-derived SNP markers for Tm-2 loci in 23 tomato genotypes.

\begin{tabular}{|c|c|c|c|c|c|c|c|c|c|c|c|c|c|}
\hline \multirow[b]{2}{*}{$\begin{array}{l}\text { Cultivar/ } \\
\text { accession }\end{array}$} & \multirow{2}{*}{$\begin{array}{c}\text { Genotype } \\
\text { at } T m-2 \\
\text { locus }\end{array}$} & \multicolumn{5}{|c|}{ Allele-specific PCR ${ }^{\mathrm{a}}$} & \multicolumn{4}{|c|}{ Allele-derived CAPS } & \multicolumn{3}{|c|}{$\begin{array}{l}\text { SNP genotyping } \\
\text { by Sequenom }\end{array}$} \\
\hline & & $\begin{array}{l}\text { Tm2S-f1/ } \\
\text { Tn2S-r1 }\end{array}$ & $\begin{array}{l}\text { Tm2S-f2/ } \\
\text { Tm2S-r2 }\end{array}$ & $\begin{array}{c}\text { Tm2R-f1 } \\
\text { c/ } \\
\text { Tm2R-r3 }\end{array}$ & $\begin{array}{l}\text { Tm2R-f1c/ } \\
\text { Tm2aR-r3 }\end{array}$ & $\begin{array}{l}\text { Tm2R-fi } \\
\text { c/Tm2-r } \\
4\end{array}$ & $\underset{\mathbf{f} 3 / \mathbf{r} 3}{\text { Tm2rs- }}$ & PshAI & HpaI & BsiHKAI & $\begin{array}{l}\text { Tm2- } \\
\text { snp1 }\end{array}$ & $\begin{array}{l}\text { Tm2- } \\
\text { snp46 }\end{array}$ & $\begin{array}{l}\text { Tm2- } \\
\text { snp53 }\end{array}$ \\
\hline NY07-461 & $\mathrm{tm}-2 / \mathrm{tm}-2$ & + & + & - & - & - & $703 \mathrm{bp}$ & $\begin{array}{c}538 \mathrm{bp} \\
+165 \mathrm{bp}\end{array}$ & $703 \mathrm{bp}$ & $703 \mathrm{bp}$ & $\mathrm{T} \mathrm{T}$ & $\mathrm{C} \mathrm{C}$ & G G \\
\hline NY07-464 & $t m-2 / t m-2$ & + & + & - & - & - & $703 \mathrm{bp}$ & $\begin{array}{l}538 \mathrm{bp} \\
+165 \mathrm{bp}\end{array}$ & $703 \mathrm{bp}$ & $703 \mathrm{bp}$ & $\mathrm{T} \mathrm{T}$ & $\mathrm{C} \mathrm{C}$ & G G \\
\hline Riesentraube & $t m-2 / t m-2$ & + & + & - & - & - & $703 \mathrm{bp}$ & $\begin{aligned} & 538 \mathrm{bp} \\
+ & 165 \mathrm{bp}\end{aligned}$ & $703 \mathrm{bp}$ & $703 \mathrm{bp}$ & $\mathrm{T} \mathrm{T}$ & $\mathrm{C} \mathrm{C}$ & G G \\
\hline LA0656 & $\mathrm{tm}-2 / \mathrm{tm}-2$ & + & + & - & - & - & $703 \mathrm{bp}$ & $\begin{array}{l}538 \mathrm{bp} \\
+165 \mathrm{bp}\end{array}$ & $703 \mathrm{bp}$ & $703 \mathrm{bp}$ & $\mathrm{T} \mathrm{T}$ & $\mathrm{C} \mathrm{C}$ & G G \\
\hline LA1792 & $t m-2 / t m-2$ & + & + & - & - & - & $703 \mathrm{bp}$ & $\begin{array}{l}538 b p \\
+165 b p\end{array}$ & $703 \mathrm{bp}$ & $703 \mathrm{bp}$ & $\mathrm{T} \mathrm{T}$ & $\mathrm{C} \mathrm{C}$ & G G \\
\hline LA1802 & $t m-2 / t m-2$ & + & + & - & - & - & $703 \mathrm{bp}$ & $\begin{aligned} & 538 \mathrm{bp} \\
+ & 165 \mathrm{bp}\end{aligned}$ & $703 \mathrm{bp}$ & $703 \mathrm{bp}$ & $\mathrm{T} \mathrm{T}$ & $\mathrm{C} \mathrm{C}$ & G G \\
\hline LA3386 & $t m-2 / t m-2$ & + & + & - & - & - & $703 \mathrm{bp}$ & $\begin{aligned} & 538 \mathrm{bp} \\
+ & 165 \mathrm{bp}\end{aligned}$ & $703 \mathrm{bp}$ & $703 \mathrm{bp}$ & $\mathrm{T} \mathrm{T}$ & $\mathrm{C} \mathrm{C}$ & G G \\
\hline $\begin{array}{l}\text { Anahu } \\
\text { (LA0655) }\end{array}$ & $t m-2 / t m-2$ & + & + & - & - & - & 703 bp & $\begin{array}{l}538 \mathrm{bp} \\
+165 \mathrm{bp}\end{array}$ & $703 \mathrm{bp}$ & $703 \mathrm{bp}$ & $\mathrm{T} \mathrm{T}$ & $\mathrm{C} \mathrm{C}$ & G G \\
\hline $\begin{array}{l}\text { Motelle } \\
\text { (LA2823) }\end{array}$ & $t m-2 / t m-2$ & + & + & - & - & - & 703 bp & $\begin{array}{l}538 \mathrm{bp} \\
+165 \mathrm{bp}\end{array}$ & $703 \mathrm{bp}$ & $703 \mathrm{bp}$ & $\mathrm{T} \mathrm{T}$ & $\mathrm{C} \mathrm{C}$ & G G \\
\hline $\begin{array}{l}\text { Mobox } \\
\text { (LA2821) }\end{array}$ & $t m-2 / t m-2$ & + & + & - & - & - & $703 \mathrm{bp}$ & $\begin{array}{c}538 \mathrm{bp} \\
+165 \mathrm{bp}\end{array}$ & $703 \mathrm{bp}$ & $703 \mathrm{bp}$ & $\mathrm{T} \mathrm{T}$ & $\mathrm{C} \mathrm{C}$ & G G \\
\hline $\begin{array}{l}\text { Ontario } 7710 \\
\text { (LA2396) }\end{array}$ & $t m-2 / t m-2$ & + & + & - & - & - & 703 bp & $\begin{array}{c}538 \mathrm{bp} \\
+165 \mathrm{bp}\end{array}$ & $703 \mathrm{bp}$ & $703 \mathrm{bp}$ & $\mathrm{T} \mathrm{T}$ & $\mathrm{C} \mathrm{C}$ & G G \\
\hline $\begin{array}{l}\text { Peto 95-43 } \\
\text { (LA3528) }\end{array}$ & $t m-2 / t m-2$ & + & + & - & - & - & 703 bp & $\begin{array}{c}538 \mathrm{bp} \\
+165 \mathrm{bp}\end{array}$ & $703 \mathrm{bp}$ & $703 \mathrm{bp}$ & $\mathrm{T} \mathrm{T}$ & $\mathrm{C} \mathrm{C}$ & G G \\
\hline $\begin{array}{l}\text { Rehovot } 13 \\
\text { (LA3129) }\end{array}$ & $t m-2 / t m-2$ & + & + & - & - & - & 703 bp & $\begin{array}{l}538 \mathrm{bp} \\
+165 \mathrm{bp}\end{array}$ & $703 \mathrm{bp}$ & $703 \mathrm{bp}$ & $\mathrm{T} \mathrm{T}$ & $\mathrm{C} \mathrm{C}$ & G G \\
\hline $\begin{array}{l}\text { UC-204C } \\
\text { (LA3130) }\end{array}$ & $t m-2 / t m-2$ & + & + & - & - & - & 703 bp & $\begin{array}{l}538 \text { bp } \\
+165 \text { bp }\end{array}$ & $703 \mathrm{bp}$ & $703 \mathrm{bp}$ & $\mathrm{T} \mathrm{T}$ & $\mathrm{C} \mathrm{C}$ & G G \\
\hline $\begin{array}{l}\text { Royal Red } \\
\text { Cherry } \\
\text { (LA2088) }\end{array}$ & $T m-2 / T m-2$ & - & - & + & - & + & 703 bp & $703 \mathrm{bp}$ & $\begin{array}{l}458 b p \\
+245 b p\end{array}$ & $\begin{array}{l}358 \text { bp } \\
+353 b p\end{array}$ & $\mathrm{C} \mathrm{C}$ & $\mathrm{T} \mathrm{T}$ & A A \\
\hline $\begin{array}{l}\text { CLN2264F } \\
\text { (LA4285) }\end{array}$ & $T m-2 / T m-2$ & - & - & + & - & + & 703 bp & $703 \mathrm{bp}$ & $\begin{array}{c}458 \mathrm{bp} \\
+245 \mathrm{bp}\end{array}$ & $\begin{array}{l}358 \mathrm{bp} \\
+353 \mathrm{bp}\end{array}$ & $\mathrm{C} \mathrm{C}$ & $\mathrm{T} \mathrm{T}$ & A A \\
\hline LA3433 & $T m-2 / T m-2$ & - & - & + & - & + & 703 bp & $703 \mathrm{bp}$ & $\begin{array}{l}458 b p \\
+245 b p\end{array}$ & $\begin{array}{l}358 \mathrm{bp} \\
+353 \mathrm{bp}\end{array}$ & $\mathrm{C} \mathrm{C}$ & $\mathrm{T} \mathrm{T}$ & A A \\
\hline $\begin{array}{l}\text { Mogeor } \\
\text { (LA3471) }\end{array}$ & $\begin{array}{l}T m-2^{2} / \\
T m-2^{2}\end{array}$ & - & - & - & + & + & 703 bp & $703 \mathrm{bp}$ & $\begin{array}{l}458 \mathrm{bp} \\
+245 \mathrm{bp}\end{array}$ & $703 \mathrm{bp}$ & $\mathrm{C} \mathrm{C}$ & $\mathrm{T} \mathrm{T}$ & A G \\
\hline Sophya & $\begin{array}{l}T m-2^{2} / \\
T m-2^{2}\end{array}$ & - & - & - & + & + & 703 bp & $703 \mathrm{bp}$ & $\begin{array}{l}458 b p \\
+245 b p\end{array}$ & $703 \mathrm{bp}$ & $\mathrm{C} \mathrm{C}$ & $\mathrm{T} \mathrm{T}$ & A A \\
\hline $\begin{array}{l}\text { VFNT Cherry } \\
\text { (LA1221) }\end{array}$ & $\begin{array}{l}T m-2^{2} / \\
T m-2^{2}\end{array}$ & - & - & - & + & + & 703 bp & $703 \mathrm{bp}$ & $\begin{array}{c}458 \mathrm{bp} \\
+245 \mathrm{bp}\end{array}$ & $703 \mathrm{bp}$ & $\mathrm{C} \mathrm{C}$ & $\mathrm{T} \mathrm{T}$ & A A \\
\hline Swt Cluster & $T m-2^{2} / t m-2$ & + & + & - & + & + & 703 bp & $\begin{aligned} & 703 \mathrm{bp} \\
+ & 538 \mathrm{bp} \\
+ & 165 \mathrm{bp}\end{aligned}$ & $\begin{array}{r}703 \text { bp } \\
+458 b p \\
+245 b p\end{array}$ & $703 \mathrm{bp}$ & $\mathrm{C} \mathrm{T}$ & $\mathrm{C} \mathrm{T}$ & A G \\
\hline Bush Celebrity & $T m-2^{2} / t m-2$ & + & + & - & + & + & 703 bp & $\begin{array}{r}703 b p \\
+538 b p \\
+165 b p\end{array}$ & $\begin{array}{r}703 b p \\
+458 b p \\
+245 b p\end{array}$ & $703 \mathrm{bp}$ & $\mathrm{C} \mathrm{T}$ & $\mathrm{C} \mathrm{T}$ & A G \\
\hline Golden Girl & $T m-2^{2} / t m-2$ & + & + & - & + & + & 703 bp & $\begin{array}{r}703 \mathrm{bp} \\
+538 \mathrm{bp} \\
+165 \mathrm{bp}\end{array}$ & $\begin{array}{r}703 \mathrm{bp} \\
+458 \mathrm{bp} \\
+245 \mathrm{bp}\end{array}$ & $703 \mathrm{bp}$ & $\mathrm{C} \mathrm{T}$ & $\mathrm{C} \mathrm{T}$ & A G \\
\hline
\end{tabular}

a c + ' signifies the PCR fragment (band) present and '-' signifies the PCR fragment (band) absent; ${ }^{\mathrm{b}}$ The SNP type such as [A T] signifies a heterogeneous SNP type and [A A] signifies a homogenous SNP type. 
Table 2. Allele-derived PCR primers and their locations in the sequences of $\mathbf{T m}-2$ loci.

\begin{tabular}{|c|c|c|c|c|c|}
\hline $\begin{array}{c}\text { Primer }^{\mathrm{a}} \\
\text { name }\end{array}$ & Sequence (5’ -> 3’) & $\operatorname{Tm}\left({ }^{\circ} \mathrm{C}\right)$ & $\begin{array}{c}\text { AF536199 } \\
\text { (tm-2) }\end{array}$ & $\begin{array}{c}\text { AF536200 } \\
(T m-2)\end{array}$ & $\begin{array}{c}\text { AF536201 } \\
\left(T m-2^{2}\right)\end{array}$ \\
\hline Tm2RS-f2 & TGCCAAACAAATTGGACTGA & 60.1 & $869-888^{\mathbf{b}}$ & $868-887$ & $6929-6948$ \\
\hline Tm2RS-r2 & AAGCACGAATTTCATGGTCC & 60 & $1458-1439$ & $1457-1438$ & $7518-7499$ \\
\hline Tm2RS-f3 & TGGAGGGGAATATTTGTGGA & 60.1 & $1966-1985$ & $1965-1984$ & $8026-8045$ \\
\hline Tm2RS-r3 & ACTTCAGACAACCCATTCGG & 60 & $2668-2649$ & $2667-2648$ & $8728-8709$ \\
\hline Tm2S-f1 & CAGTGATCCGAGTGAGCAAA & 60 & $2357-2376$ & - & - \\
\hline Tm2S-r1 & TTCCGATAAACTGATTCCGC & 60 & $2750-2731$ & - & - \\
\hline $\operatorname{Tm} 2 \mathrm{~S}-\mathrm{f} 2$ & СTTCCTTCTGGTGTTTGGGA & 60.1 & $2058-2077$ & - & - \\
\hline Tm2S-r2 & CAGAACCTTTAGCGCCTTTG & 60 & $2342-2323$ & - & - \\
\hline Tm2R-f1c & СТCCTTCTGGTGTTTGGGAG & 59.7 & - & $2058-2077$ & $8119-8138$ \\
\hline Tm2R-r3 & CGGTCTACCGTAAAGTTGGC & 59.6 & - & $2502-2483$ & - \\
\hline Tm2aR-r3 & CGGTCTACACTAAAGTAGGC & 59.6 & - & - & $8563-8544$ \\
\hline Tm2R-r4 & AGTACTGCCAGTATATAACG & 53.9 & - & $2520-2501$ & $8579-8562$ \\
\hline
\end{tabular}

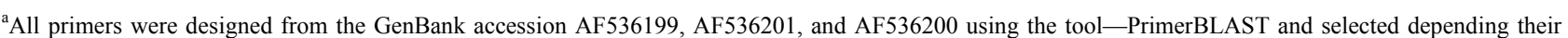
allele-specificity The forward primers, Tm2RS-f2, and Tm2RS-f3, and the reverse primers, Tm2RS-r2, and Tm2RS_r3 were specific for the AF536199, AF536201, and AF536200; the forward primers, Tm2S-f1 and Tm2S-f2, and reverse primers, Tm2S-r1 and Tm2S-r2 specific for AF536199; and the forward primer, Tm2R-f1c for AF536199 and AF536200; the reverse primer Tm2R-r3 for AF536200; and the reverse primer Tm2aR-r3 for AF536201; ${ }^{\mathrm{b}}$ The primer location presenting the corresponding site in the GenBank accession For example, the primer Tm2RS_f 2 is located at $869-888$ sites of the GenBank accession AF536199; and '-' signifies the primer sequence does not exist in the corresponding sequence.

Table 3. PCR conditions for different primer pairs.

\begin{tabular}{|c|c|c|c|c|c|c|c|}
\hline \multirow[b]{2}{*}{ Primer pair } & \multicolumn{3}{|c|}{ Denaturation } & \multicolumn{2}{|c|}{ Annealing } & \multicolumn{2}{|c|}{ Extension } \\
\hline & Cycle & Temperature & Time & Temperature & Time & Temperature & Time \\
\hline Tm2RS-f2/Tm2RS-r2,Tm2RS-f3/Tm2RS-r3 & 38 & $94^{\circ} \mathrm{C}$ & $30 \mathrm{~s}$ & $53^{\circ} \mathrm{C}$ & $30 \mathrm{~s}$ & $72^{\circ} \mathrm{C}$ & $75 \mathrm{~s}$ \\
\hline Tm2S-f1/Tm2S-r1, Tm2S-f2/Tm2S-r2 & 36 & $94^{\circ} \mathrm{C}$ & $15 \mathrm{~s}$ & $56^{\circ} \mathrm{C}$ & $25 \mathrm{~s}$ & $72^{\circ} \mathrm{C}$ & $40 \mathrm{~s}$ \\
\hline Tm2R-f1c/Tm2R-r3 and Tm2R-f1c/Tm2aR-r3 & 36 & $94^{\circ} \mathrm{C}$ & $20 \mathrm{~s}$ & $56^{\circ} \mathrm{C}$ & $25 \mathrm{~s}$ & $72^{\circ} \mathrm{C}$ & $55 \mathrm{~s}$ \\
\hline Tm2R-f1c/Tm2R-r4 & 36 & $94^{\circ} \mathrm{C}$ & $20 \mathrm{~s}$ & $51^{\circ} \mathrm{C}$ & $25 \mathrm{~s}$ & $72^{\circ} \mathrm{C}$ & $55 \mathrm{~s}$ \\
\hline
\end{tabular}

genotypes with and without Tm-2. The PCR fragments were sequenced in the Purdue Genomics Core Facility, Purdue University. The sequences amplified from the primer pairs Tm2RS-f2/r2 and Tm2RS-f3/r3 were aligned using the software BioEdit v 7.0.5 (http://www. mbio.ncsu.edu/bioedit/bioedit.html). SNPs were extracted from the alignment by TASSEL2.1 [26]. SNP genotyping was done at the Sequenom Technology Core, the Division of Human Genetics in the Department of Genetics, Washington University, St. Louis, MO 63110 (http://hg. wustl.edu/info/Sequenom_description.html). Three SNPs were used for SNP genotyping in 23 tomato genotypes using Sequnom. The primers and the multiplex assay are list in supplementary Table S1 consisting of 3 SNPs iPLEX, which was designed by the tool-Assay Design 3 specific for iPLEX genotyping on MassARRAY sys- tem by Sequenom; the software Assay Design can be downloaded from Sequnom web site (https://www.mysequenom.com) after registration.

\subsection{CAPS Marker}

From the three sequences of AF536199, AF536200, and AF536201 at Tm-2 locus, seven enzymes, BseYI, BsiHKAI, BsmI, BtsI, HpaI, PciI, and PshAI can cut at different sites and produce different DNA fragments using the tool-NEBcutter V2.0 (http://tools.neb.com/ NEBcutter2) (Table 4). Three out of the seven enzymes, PshAI, HpaI, and BsiHKAI were used to digest the PCR fragments amplified from the primer pair Tm2RS-f3/r3 among 23 tomato genotypes with and without $\mathrm{Tm}-2$ following the manufacturer's instructions (New England Biolabs Inc.) (Table 4). For enzyme HpaI, each digestion 
Table S1. Primer properties in the SNP assay for Sequenom SNP genotyping.

\begin{tabular}{|c|c|c|c|c|c|c|}
\hline SNP_ID & $\begin{array}{l}\text { SNP } \\
\text { type }\end{array}$ & 2nd-PCRP & 1st-PCRP & $\begin{array}{l}\text { AMP } \\
\text { LEN }\end{array}$ & $\begin{array}{l}\text { UEP } \\
\text { MASS }\end{array}$ & UEP_SEQ \\
\hline Tm2-snp1 & $\mathrm{C} / \mathrm{T}$ & $\begin{array}{l}\text { ACGTTGGATGCACACGTCTA- } \\
\text { GAGACCATAG }\end{array}$ & $\begin{array}{l}\text { ACGTTGGATGTGTTTA- } \\
\text { GACTCCCAAACACC }\end{array}$ & 95 & 6326 & $\begin{array}{l}\text { cTCGACG- } \\
\text { TAGCCTCATTCAAC }\end{array}$ \\
\hline Tm2-snp46 & $\mathrm{C} / \mathrm{T}$ & $\begin{array}{c}\text { ACGTTGGATGTAGTTGGGCCAA } \\
\text { TGCTTCAC }\end{array}$ & $\begin{array}{c}\text { ACGTTGGATGTATGGCTAGCGGT } \\
\text { ATACCTC }\end{array}$ & 102 & 7495 & $\begin{array}{l}\text { TGGTGAATATTGGTA } \\
\text { GAAATATAG }\end{array}$ \\
\hline Tm2-snp53 & $\mathrm{A} / \mathrm{G}$ & $\begin{array}{c}\text { ACGTTGGAT- } \\
\text { GATCTTCTCAATCTCCATAGC }\end{array}$ & $\begin{array}{l}\text { ACGTTGGATGCTCTTAGAT- } \\
\text { GACTTCCTTCC }\end{array}$ & 124 & 6937 & $\begin{array}{l}\text { gCAATCTCCATAG- } \\
\text { CAAACTCATC }\end{array}$ \\
\hline
\end{tabular}

Table 4. Enzyme cut sites in the sequences of $\mathbf{T m}-2$ locus.

\begin{tabular}{|c|c|c|c|c|}
\hline \multirow{3}{*}{ Enzyme } & \multirow{3}{*}{ Specificity } & \multicolumn{3}{|c|}{ Cut position ${ }^{a}$} \\
\hline & & AF536199 & AF536200 & AF536201 \\
\hline & & $(t m-2)$ & $(T m-2)$ & $\left(T m-2^{2}\right)$ \\
\hline BseYI & C CCAG C & $1230 / 1234$ & - & - \\
\hline \multirow{2}{*}{ BsiHKAI } & \multirow{2}{*}{ G WGCW C } & \multirow{2}{*}{-} & $2322 / 2318$ & $3776 / 3772,8736 / 8732$ \\
\hline & & & $2675 / 2671$ & 9836/9832 \\
\hline BsmI & GAATG CN & $2451 / 2449$ & - & $3000 / 2998$ \\
\hline BtsI & GCAGTG NN & $2521 / 2519$ & - & $3576 / 3574$ \\
\hline HpaI & GTT AAC & - & 2422 & $2835,5643,8483,9325$ \\
\hline PciI & A CATG T & $2307 / 2311$ & - & $3508 / 3512$ \\
\hline PshAI & GACNN NNGTC & 2503 & - & 3509 \\
\hline \multirow{3}{*}{ Enzyme } & \multirow{3}{*}{ Specificity } & \multicolumn{3}{|c|}{ PCR fragments amplified from Tm2RS-f3/r3 } \\
\hline & & $\begin{array}{l}\text { FJ817600 } \\
\text { FJ817607 }\end{array}$ & $\begin{array}{l}\text { FJ817605 } \\
\text { FJ817604 }\end{array}$ & $\begin{array}{l}\text { FJ817606 } \\
\text { FJ817602 }\end{array}$ \\
\hline & & $(t m-2)$ & $(T m-2)$ & $\left(T m-2^{2}\right)$ \\
\hline BsiHKAI & G WGCW C & - & $358 / 354$ & - \\
\hline HpaI & GTT AAC & - & 458 & 458 \\
\hline PshAI & GACNN NNGTC & 538 & - & - \\
\hline
\end{tabular}

${ }^{a}$ Cut position location by the enzyme in the corresponding accession sequence such as the enzyme BseYI cut the AF536199 sequence at 1230 and 1234 base but not cut the sequences of AF536200 and AF536201. ' AF536199b, AF536200, AF536201, FJ817600, FJ817607, FJ817605, FJ817604, FJ817606, and FJ817602 are GenBank accessions at Tm-2 locus.

reaction consisted of $2.0 \mu \mathrm{l} 10 \mathrm{X}$ NEBuffer $4,0.4 \mu \mathrm{l}$ restriction enzyme $(5 \mathrm{U} / \mu \mathrm{l})$, and $17.6 \mu \mathrm{l}$ direct PCR product. For enzyme BsiHKAI, each digestion reaction consisted of $2.0 \mu \mathrm{l} 10 \mathrm{X}$ NEBuffer $3,0.2 \mu 1$ acetylated BSA (10 $\mu \mathrm{g} / \mu \mathrm{l}), 0.2 \mu \mathrm{l}$ restriction enzyme $(10 \mathrm{U} / \mu \mathrm{l})$, and $17.6 \mu \mathrm{l}$ direct PCR product. For enzyme PshAI, each digestion reaction consisted of $2.0 \mu \mathrm{l} 10 \mathrm{X}$ NEBuffer $4,0.2 \mu \mathrm{l}$ acetylated BSA $(10 \mu \mathrm{g} / \mu \mathrm{l}), 0.2 \mu \mathrm{l}$ restriction enzyme (10 $\mathrm{U} / \mu 1$ ), and $17.6 \mu \mathrm{l}$ direct PCR product. Digestion mixture was incubated at $37^{\circ} \mathrm{C}$ in an eppendorf thermal cycler for $3 \mathrm{hr}$. The digestion products were visualized in $1.5 \%$ agarose gels in $0.5 \mathrm{X}$ TBE, stained with ethidium bromide.

\section{Results}

\subsection{Allele-Specific PCR Markers}

Two primer pairs, Tm2S-f1/Tm2S-r1 and Tm2S-f2/ Tm2S-r2, amplified to produce DNA fragment only for the 14 tomato genotypes containing susceptible allele tm-2 with homozygous (tm-2/tm-2) or heterozygous $\left(\mathrm{Tm}-2^{2} / \mathrm{tm}-2\right)$ condition as codominant marker (Table 1), 
indicating the two primers can be used as PCR-based markers to select the susceptible allele $t m-2$ in tomato. The primer pair Tm2R-f1c/Tm2R-r3 only amplified the tomato genotypes containing resistance allele $\mathrm{Tm}-2$. However, the primer pair Tm2R-f1c/Tm2aR-r3 amplified the tomato genotypes with $\mathrm{Tm}-2^{2}$ with homozygous or heterozygous condition. The primer pair $\mathrm{Tm} 2 \mathrm{R}-\mathrm{f} 1 \mathrm{c} /$ Tm2R-r4 amplified the DNA from tomato genotypes containing either $T m-2$ or $T m-2^{2}$ with homozygous or heterozygous condition, indicating the primer pair can be used to select either $T m-2$ or $T m-2^{2}$ gene (Table 1).

\subsection{Allele-Derived CAPS Markers}

The enzyme PshAI cut the PCR fragment amplified with the primer pair Tm2RS-f3/r3 at the site 537 base into two fragments with the size of $538 \mathrm{bp}$ and $165 \mathrm{bp}$ for the tomatoes containing susceptible allele tm-2; The enzyme HapI cut the PCR fragment into 458 bp and 245 bp among those tomatoe lines carrying either $T m-2$ or $T m 2^{2}$ and; BsiHKAI cut the fragment into $358 \mathrm{bp}$ and $353 \mathrm{bp}$ in those containing $\mathrm{Tm}-2$ (Table 1). This indicated that combination of the three markers can be used to identify and distinguish the three alleles at $\mathrm{Tm}-2$ locus in tomato lines.

\subsection{Gene-Derived SNP Markers}

Both SNP Tm2-snp1 and Tm2-snp46 had three types of SNP [C C], [T T], and [C T] showing co-dominant pattern (Table 1). The type [T T] in Tm2-snp1 and [C C] in Tm2-snp46 were specific for those tomato genotypes containing susceptible homozygous alleles $t m-2 / t m-2$. On the other hand, the type [C C] in Tm2-snp1 and [T T] in Tm2-snp46 were specific to those tomato genotypes carrying resistance homozygous alleles $\mathrm{Tm}-2 / \mathrm{Tm}-2$ or $\mathrm{Tm} 2^{2} / \mathrm{Tm} 2^{2}$. [C T] in both SNPs was for the three tomato genotypes containing heterozygous $\mathrm{Tm} 2^{2} / \mathrm{tm}-2$. The SNP Tm2-snp53 had three types [A A], [A G], and [G G]. The tomato lines containing homozygous or heterozygous alleles for resistance allele $T m-2$ or $T m 2^{2}$ had the SNP Tm2-snp53 type [A A] or [A G], but those carrying homozygous susceptible allele tm-2 had [G G] type in Tm2snp53 (Table 1). Results indicated that these SNPs can differentiate resistance and susceptible allele at $\mathrm{Tm}-2$ locus.

\subsection{Sequence Analysis and Potential SNP Identification}

The primer pairs Tm2RS-f2/r2 and Tm2RS-f3/r3 produced DNA fragments with the size of $490 \mathrm{bp}$, and 703 bp, respectively in all 23 tomato genotypes (Table 1). The 13 DNA fragment sequences amplified from the two primer pair were stored at GenBank with the accessions no. from FJ17595 to FJ17607.

From the multiple sequence alignment among the eight
PCR fragments (FJ17600 to FJ17607) amplified from the primer pair Tm2RS-f3/r3 with the corresponding DNA segments of the AF536201, AF536200, AY742887, and AF536199, 40 SNPs were found (Supplementary Table S2). Among them, 36 SNPs were capable to discriminate the tomato genotypes with the susceptible allele $t m-2$ and those with the resistance alleles either $T m-2$ or $T m-2^{2}$. Four SNPs, SNP9, SNP30, SNP32, and SNP33 were further capable to differentiate the genotypes carrying $T m-2$ and $T m-2^{2}$. Two SNPs, SNP9 and SNP32 had triple alleles. SNP1 [C/T] was selected as one of the multiplex assay for SNP genotyping in 23 tomato genotypes by Sequenom.

From the multiple sequence alignment among the five PCR fragments (FJ17595 to FJ17599) amplified from the primer pair Tm2RS-f2/r2 with the corresponding DNA segments of the AF536201, AF536200, AY742887, and AF536199, eight SNPs were observed (Supplementary Table S3). Among them, six SNPs showed the differences between the tomato lines with susceptible allele $t m-2$ and resistance alleles including $T m-2$ or $T m-2^{2}$. Two SNPs, SNP42 and SNP45 showed the differences between those carrying $T m-2$ and $T m-2^{2}$. SNP46 [C/T] was also selected as one of the multiplex assay for SNP genotyping in 23 tomato genotypes by Sequenom.

Besides the 48 SNPs verified from the re-sequencing of the PCR products amplified the two primer pairs, ten SNPs and one InDel were also postulated among the three Tm-2 sequences AF536201, AF536200, and AF536199 (Supplementary Table S4). Among them, nine SNPs and one InDel showed the difference between the tomato genotypes with susceptible allele tm-2 and resistance alleles including $T m-2$ or $T m-2^{2}$. The SNP SNP53 showed the difference between $T m-2$ and $T m-2^{2}$ and was selected as one of the multiplex assay for SNP genotyping in 23 tomato genotypes by Sequenom.

\section{Discussion}

Three types of molecular marker development for Tm-2 loci were developed in this research. From known Tm-2 gene cloning sequences AF536199 (tm-2), AF536200 $(T m-2)$, and AF536201 $\left(T m-2^{2}\right)$, two gene-specific primer pairs, Tm2RS-f2/r2 and Tm2RS-f $3 / \mathrm{r} 3$ were designed. The PCR products amplified from tomato genotypes contained either resistance allele $T m-2, T m-2^{2}$ or susceptible allele tm-2 using the two primer pairs were sequenced. After multiple sequence alignment, 40 SNPs were found and validated from the sequences amplified from Tm2RS-f3/r3 (Table S2) and eight SNPs and one InDel from Tm2RS-f2/r2 (Table S3). Two SNPs, snp1 and snp46 selected from sequences amplified from the two primer pairs plus the SNP snp53 picked up from other location of the sequence (Table S4) were selected 


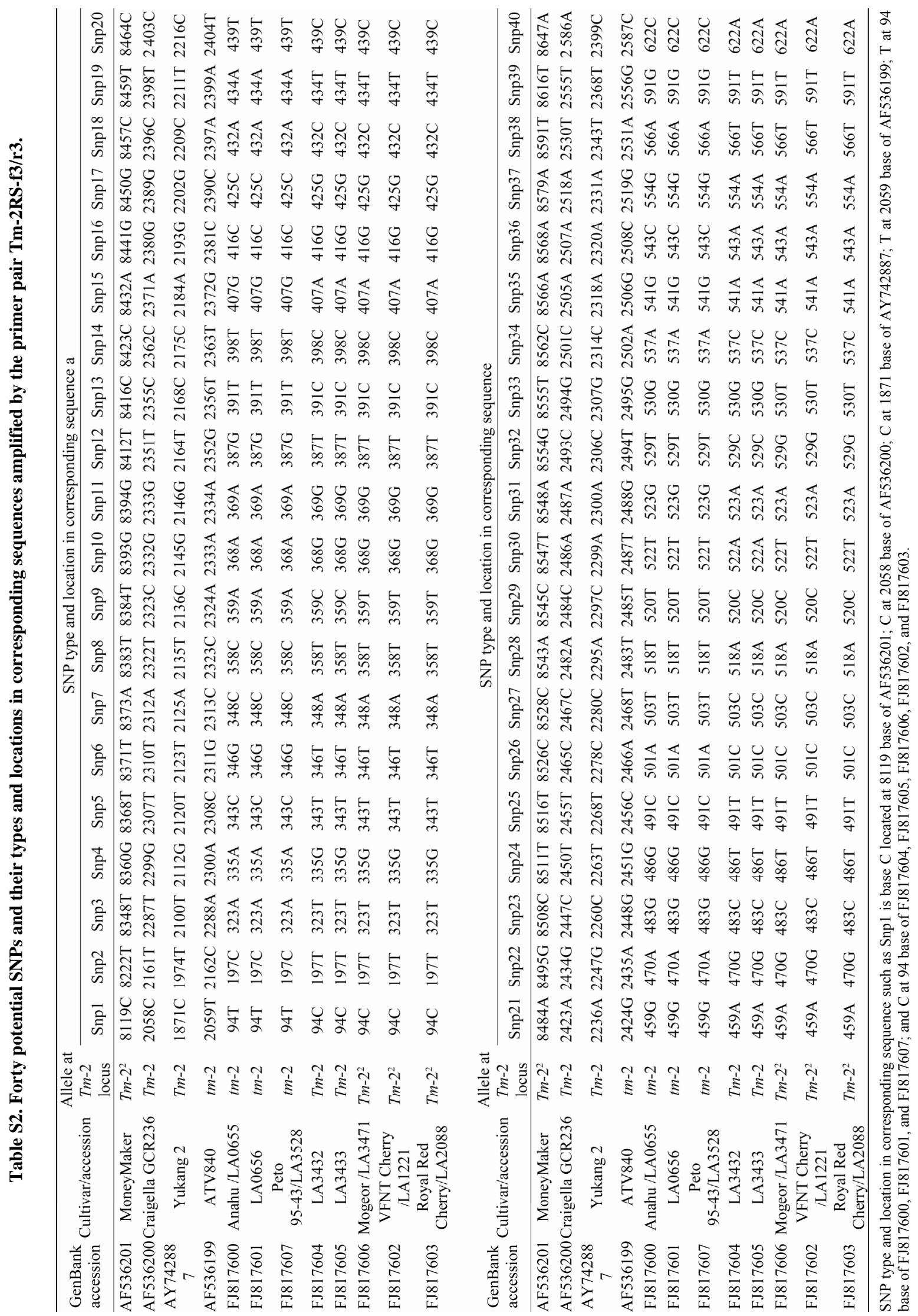


Table S3. Eight potential SNPs and their types and locations in corresponding sequences amplified by the primer pair Tm-2RS-f2/r2.

\begin{tabular}{|c|c|c|c|c|c|c|c|c|c|c|}
\hline \multirow{2}{*}{$\begin{array}{l}\text { GenBank } \\
\text { accession }\end{array}$} & \multirow{2}{*}{$\begin{array}{l}\text { Cultivar/ } \\
\text { accession }\end{array}$} & \multirow{2}{*}{$\begin{array}{l}\text { Allele at } \\
T m-2 \text { locus }\end{array}$} & \multicolumn{8}{|c|}{ SNP type and location in corresponding sequence ${ }^{a}$} \\
\hline & & & SNP41 & SNP42 & SNP43 & SNP44 & SNP45 & SNP46 & SNP47 & SNP48 \\
\hline AF536201 & MoneyMaker & $T m-2^{2}$ & $6962 \mathrm{G}$ & 7017A & $7043 \mathrm{G}$ & $7085 \mathrm{~T}$ & $7106 \mathrm{G}$ & $7291 \mathrm{~T}$ & $7454 \mathrm{~T}$ & $7485 \mathrm{G}$ \\
\hline AF536200 & Craigella GCR236 & $\operatorname{Tm} 2$ & $901 \mathrm{G}$ & $956 \mathrm{~T}$ & $982 \mathrm{G}$ & $1024 \mathrm{~T}$ & $1045 \mathrm{~T}$ & $1230 \mathrm{~T}$ & $1393 \mathrm{~T}$ & $1424 \mathrm{G}$ \\
\hline AF536199 & ATV840 & $t m-2$ & $902 \mathrm{~T}$ & $957 \mathrm{~A}$ & $983 \mathrm{~T}$ & $1025 \mathrm{C}$ & $1046 \mathrm{G}$ & $1231 \mathrm{C}$ & $1394 \mathrm{G}$ & $1425 \mathrm{~A}$ \\
\hline AY742887 & Yukang 2 & $\operatorname{Tm} 2$ & $714 \mathrm{G}$ & $769 \mathrm{~T}$ & $795 \mathrm{G}$ & $837 \mathrm{~T}$ & $858 \mathrm{~T}$ & $1043 \mathrm{~T}$ & $1206 \mathrm{~T}$ & $1237 \mathrm{G}$ \\
\hline FJ817595 & Anahu/LA0655 & $\operatorname{tm} 2$ & $34 \mathrm{~T}$ & $89 \mathrm{~A}$ & $115 \mathrm{~T}$ & $157 \mathrm{C}$ & $178 \mathrm{G}$ & $363 \mathrm{C}$ & $526 \mathrm{G}$ & $557 \mathrm{~A}$ \\
\hline FJ817596 & LA0656 & $\operatorname{tm} 2$ & $34 \mathrm{~T}$ & $89 \mathrm{~A}$ & $115 \mathrm{~T}$ & $157 \mathrm{C}$ & $178 \mathrm{G}$ & $363 \mathrm{C}$ & $526 \mathrm{G}$ & $557 \mathrm{~A}$ \\
\hline FJ817599 & Peto $95-43 /$ LA3528 & $\operatorname{tm} 2$ & $34 \mathrm{~T}$ & $89 \mathrm{~A}$ & $115 \mathrm{~T}$ & $157 \mathrm{C}$ & $178 \mathrm{G}$ & $363 \mathrm{C}$ & $526 \mathrm{G}$ & $557 \mathrm{~A}$ \\
\hline FJ817597 & VFNT Cherry/LA1221 & $T m-2^{2}$ & $34 \mathrm{G}$ & $89 \mathrm{~A}$ & $115 \mathrm{G}$ & $157 \mathrm{~T}$ & $178 \mathrm{G}$ & $363 \mathrm{~T}$ & $526 \mathrm{~T}$ & $557 \mathrm{G}$ \\
\hline FJ817598 & LA3433 & $\operatorname{Tm} 2$ & $34 \mathrm{G}$ & $89 \mathrm{~T}$ & $115 \mathrm{G}$ & $157 \mathrm{~T}$ & $178 \mathrm{~T}$ & $363 \mathrm{~T}$ & $526 \mathrm{~T}$ & $557 \mathrm{G}$ \\
\hline
\end{tabular}

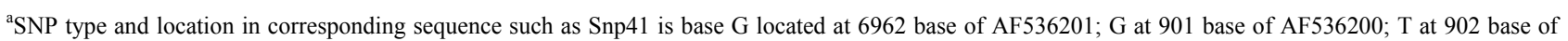
AF536199; G at 714 base of AY742887; T at 34 base of FJ817595, FJ817596, and FJ817599; and G at 34 base of FJ817597 and FJ817598.

Table S4. Ten potential SNPs and one InDel and their types and locations in corresponding sequences among Tm-2 alleles except above 48 SNPs in Table S1 and S2.

\begin{tabular}{|c|c|c|c|c|c|c|c|c|c|c|c|c|c|}
\hline \multirow{2}{*}{$\begin{array}{l}\text { GenBank } \\
\text { accession }\end{array}$} & \multirow{2}{*}{ Cultivar } & \multirow{2}{*}{$\begin{array}{c}\text { Allele at } \\
T m-2 \text { locus }\end{array}$} & \multicolumn{11}{|c|}{ SNP type and location in corresponding sequence ${ }^{a}$} \\
\hline & & & SNP49 & SNP50 & SNP51 & SNP52 & SNP53 & SNP54 & SNP55 & SNP56 & SNP57 & SNP58 & InDel1 \\
\hline AF536199 & ATV840 & $t m-2$ & $73 \mathrm{~A}$ & $109 \mathrm{~A}$ & $457 \mathrm{G}$ & $487 \mathrm{C}$ & $500 \mathrm{G}$ & $612 \mathrm{~T}$ & $704 \mathrm{C}$ & $849 \mathrm{G}$ & $2672 \mathrm{~A}$ & $2733 \mathrm{G}$ & $89 \mathrm{~A}$ \\
\hline AF536200 & $\begin{array}{l}\text { Craigella } \\
\text { GCR236 }\end{array}$ & $T m-2$ & $73 \mathrm{C}$ & $108 \mathrm{~T}$ & $456 \mathrm{~A}$ & $486 \mathrm{G}$ & $499 \mathrm{G}$ & $611 \mathrm{C}$ & $703 \mathrm{~T}$ & $848 \mathrm{~A}$ & $2671 \mathrm{G}$ & $2732 \mathrm{C}$ & $88-89 d$ \\
\hline AF536201 & MoneyMaker & $T m-2^{2}$ & $6134 \mathrm{C}$ & $6169 \mathrm{~T}$ & $6517 \mathrm{~A}$ & $6547 \mathrm{G}$ & $6560 \mathrm{~A}$ & $6672 \mathrm{C}$ & $6764 \mathrm{~T}$ & $6909 \mathrm{~A}$ & $8732 \mathrm{G}$ & $8793 \mathrm{C}$ & $88-89 d$ \\
\hline
\end{tabular}

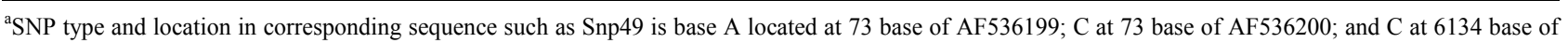
AF536201.

to use SNP genotyping for identification of Tm-2 alleles and verified that they were useful to identify difference alleles, $t m-2, T m-2$, and $T m-2^{2}$ in 23 tomato genotypes by Sequnom technology (Table 1). Meanwhile, allele-specific PCR primers were designed for each allele at Tm-2 locus and five allele-specific PCR-based markers were identified: one for $T m-2$, one for $T m-2^{2}$, one for both $T m-2$ and $T m-2^{2}$, and two for the susceptible allele $t m-2$ in 23 tomato genotypes (Table 1). The allele-derived CAPS markers were designed from the sequences amplified from primer pair Tm2RS-f3/r3 digested by the three enzymes, BsiHKAI, HpaI, and PshAI, which can identify and distinguish the three alleles, $t m-2, T m-2$, and $T m-2^{2}$ among 23 tomato genotypes (Table 1).

The five allele-specific PCR markers were dominant markers, which can't distinguish the homozygous and heterozygous genotypes at $\mathrm{Tm}-2$ locus individually, but the combination of these markers can do (Table 1). The three CAPS markers performed the same way as the allele-specific PCR-based markers did (Table 1). The two
SNP markers, snp1 and snp46 were co-dominant ones and they can distinguish the homozygous and heterozygous genotypes at Tm-2 locus individually. However, we did not identify a SNP marker that can distinguish $T m-2^{2}$ from $T m-2$. The SNP53 should distinguish $T m-2^{2}$ from Tm-2 because AF53200 (Tm-2) has a "G" at 499 base of the sequence but AF536201 (Tm- $\left.2^{2}\right)$ has an "A" base at the corresponding site of the sequence (Table S4). But our SNP genotyping data did not support Tm-2-carrying tomato lines carried a " $G$ " base in the corresponding site, such as Royal Red Cherry (LA2088), CLN2264F (LA4285), and LA3433 contained Tm-2 allele but they had [A A] type for snp53 (Table 1). Besides the snp53, SNP9, SNP30, SNP32, SNP33, SNP42, and SNP45 also showed difference in their SNP types for $T m-2^{2}$ from Tm-2 (Tables S2 and S3) and maybe they can be used in SNP genotyping for distinguishing $T m-2^{2}$ from Tm-2. But, they need to be validated in further research. However, the snp9 was validated to be used to distinguish $T m-2^{2}$ from $T m-2$ by the CAPS marker through digestion 
the PCR products amplified from Tm-2RS-f3/r3 by enzyme EsiHKAI (Tables 1 and 4). Only those tomato lines contained $T m-2$ allele were digested by EsiHKAI for the DNA segments amplified from T2RS- $\mathrm{f} 3 / \mathrm{r} 3$ because $\mathrm{Tm}-2$ carrying tomato genotypes had a " $\mathrm{C}$ " base at 359 base of the sequences but others had an " $\mathrm{A}$ " base at 359. The SNP32 in supplementary Table S2 and SNP41 in Table S3 were used as a tetra-primer ARMS-PCR assays by Arens et al. [15] to produce different PCR fragment sizes for detection of three alleles tm-2, Tm-2, and $T m-2^{2}$ in tomato genotypes.

Three types of molecular markers, allele-specific PCR, allele-derived CAPS, and allele-derived SNP were identified for the Tm-2 locus for ToMV resistance (Table 1). Lanfermeijer et al. in 2005 [14] reported three CAPS markers which can distinguish the three alleles, tm-2, $T m-2$, and $T m-2^{2}$ in tomato genotypes and the enzyme HapI was also reported that cut the same site of the sequences from resistant cultivars, Craigella GCR236 $(\mathrm{Tm}-2)$, Craigella GCR267 $\left(\mathrm{Tm} 2^{2}\right)$, and ATV847 $\left(\mathrm{Tm}^{2}\right)$, but not in the susceptible cultivars, GCR26 (tm-2) and ATV840 (tm-2). However, in their research, the primer pair, PrRuG151 (GAGTTCTTCCGTTCAAATCCTAAGCTTGAGAAG)/PrRuG086 (CTACTACACTCACGTTGCTGTGATGCAC) was used to amplify DNA fragments among the five cultivars. The primer PrRuG151 was located at 7824 to 7856 base and PrRuG086 at 8908 to 8881 base of the AF536201 sequence and the primer pair produced a 1085 bp DNA fragment. The enzyme HpaI cut the DNA fragments into two with $660 \mathrm{bp}$ and $424 \mathrm{bp}$ fregments for Craigella GCR236 (Tm-2), Craigella GCR267 $\left(T m-2^{2}\right)$, and ATV847 $\left(T m-2^{2}\right)$, but not for GCR26 (tm-2) and ATV840 (tm-2). In our research, the primer pair $\mathrm{Tm}-2 \mathrm{RS}-\mathrm{f} 3 / \mathrm{r} 3$ was used and produced a 703 bp DNA fragment of PCR products. The fragment was digested with $\mathrm{HpaI}$ into two fragments with $538 \mathrm{bp}$ and $165 \mathrm{bp}$ for tomato genotypes carrying $\mathrm{Tm}-2$ and $\mathrm{Tm}-\mathrm{2}^{2}$ but not for tm-2 (Table 1). HpaI can cut the sequence "GTT AAC" in DNA fragments amplified from prmier pair of either PrRuG151/PrRuG086 or Tm-2RS-f3/r3. Because the resistant genotypes contained $\mathrm{Tm}-2$ and $T m-2^{2}$ had the sequence "GTT AAC", but the susceptible genotypes carrying tm-2 had the "GTT GAC" in corresponding site of the sequence. The SNP snp21 in Table S2 was the same site of HpaI cutting site. These results indicated that the CAPS marker digested by HpaI and the SNP marker SNP21 $[\mathrm{A} / \mathrm{G}]$ can be used as a markers to identify and distinguish the susceptible allele tm-2 from the resistance allele $T m-2$ or $T m-2^{2}$. After all, these allele-specific PCR-based, CAPS, and gene-derived SNP markers for $T m-2$ locus will provide breeders to select the allele $t m-2, T m-2$, and $T m-2^{2}$ of ToMV resistance in advancing the MAS for tomato breeding.

\section{Acknowledgements}

We thank G. Moriarty, M. Glos and M. Jahn (Cornell University) and C. R. Lawn (Restoring our Seed) for providing tomato line NY07-461 and NY07-464 that was developed with support from USDA-SARE proposal LNE04-204 and LNE02-160. We also thank Roger Chetelat and Sheh May Tam at Tomato Genetics Resource Center, Department of Plant Sciences, University of California for providing 16 tomato accessions. We are grateful to Xianming Chen at USDA-ARS and Washington State University for review of the manuscript.

\section{REFERENCES}

[1] M. R. Foolad, "Genome Mapping and Molecular Breeding of Tomato," International Journal of Plant Genomics, Vol. 2007, 2007, Article ID 64358. doi: $10.1155 / 2007 / 64358$

[2] T. J. Hall, "Resistance at the Tm-2 Locus in the Tomato to Tomato Mosaic Virus," Euphytica, Vol. 29, No. 1, 1989, pp. 189-197. doi:10.1007/BF00037266

[3] F. C. Lanfermeijer, J. Dijkhuis, M. J. G. Sturre, P. de Haan and J. Hille, "Cloning and Characterization of the Durable Tomato Mosaic Virus Resistance Gene $T m-2^{2}$ from Lycopersicon Esculentum," Plant Molecular Biology, Vol. 52, No. 5, 2003, pp. 1037-1049. doi:10.1023/A:1025434519282

[4] H. Levesque, F. Vedel, C. Mathieu and A. G. L. de Courcel, "Identification of a Short Rdna Spacer Sequence Highly Specific of a Tomato Line Containing Tm-1 Gene Introgressed from Lycopersicon Hirsutum," Theoretical and Applied Genetics, Vol. 80, No. 5, 1990, pp. 602-608. doi:10.1007/BF00224218

[5] J. Pelham, "Resistance in Tomato to Tobacco Mosaic Virus," Euphytica, Vol. 15, 1966, pp. 258-267. doi:10.1007/BF00022331

[6] M. R. Foolad and A. Sharma, "Molecular Markers as Selection Tools in Tomato Breeding," ISHS Acta Horticulturae, Vol. 695, 2005, pp. 225-240.

[7] T. Ohmori, M. Murata and F. Motoyoshi, "Molecular Characterization of RAPD and SCAR Markers Linked to the Tm-1 Locus in Tomato," Theoretical and Applied Genetics, Vol. 92, 1996, pp. 151-156.

[8] S. D. Tanksley, M. W. Ganal, J. P. Prince, M. C. de Vicente, M. W. Bonierbale, P. Broun, T. M. Fulton, J. J. Giovannoni, S. Grandillo and G. B. Martin, "High Density Molecular Linkage Maps of the Tomato and Potato Genomes," Genetics, Vol. 132, No. 4, 1992, pp. 1141-1160.

[9] D. J. Vakalounakis, H. Laterrot, A. Moretti, E. K. Ligoxigakis and K. Smardas, "Linkage between Fr1 (Fusarium Oxysporum f sp Radicis-Lycopersici Resistance) and Tm-2 (Tobacco Mosaic Virus Resistance-2) Loci in Tomato (Lycopersicon Esculentum)," Annals of Applied Biology, Vol. 130, 1997, pp. 319-323. doi:10.1111/j.1744-7348.1997.tb06835.x

[10] T. Ohmori, M. Murata and F. Motoyoshi, "Identification 
of RAPD Markers Linked to the Tm-2 Locus in Tomato," Theoretical and Applied Genetics, Vol. 90, 1995, pp. 307-311. doi:10.1007/BF00221969

[11] F. Motoyoshi, T. Ohmori and M. Murata, "Molecular Characterization of Heterochromatic Regions around the Tm-2 Locus in Chromosome 9 of Tomato," Symposium of the Society for Experimental Biology, Vol. 50, 1996, pp. 65-70.

[12] Sobir, T. Ohmori, M. Murata and F. Motoyoshi, "Molecular Characterization of the SCAR Markers Tightly Linked to the Tm-2 Locus of the Genus Lycopersicon," Theoretical and Applied Genetics, Vol. 101, No. 1-2, 2000, pp. 64-69. doi:10.1007/s001220051450

[13] E. Dax, O. Livneh, E. Aliskevicius, N. Kedar, N. Gavish, J. Milo, F. Geffen, A. Blumenthal, H. D. Rabinowich and I. Sela, "A SCAR Marker Linked to the Tomv Resistance Gene, Tm2 $2^{2}$, in Tomato," Euphytica, Vol. 101, No. 1, May 1998, pp. 73-77. doi:10.1023/A:1018307326636

[14] F. C. Lanfermeijer, J. Warmink and J. Hille, "The Products of the Broken Tm-2 and the Durable Tm- $2^{2}$ Resistance Genes from Tomato Differ in Four Amino Acids," Journal of Experimental Botany, Vol. 56, No. 421, November 2005, pp. 2925-2933. doi:10.1093/jxb/eri288

[15] P. Arens, C. Mansilla, D. Deinum, L. Cavellini, A. Moretti, S. Rolland, H. van der Schoot, D. Calvache, F. Ponz, C. Collonnier, R. Mathis, D. Smilde, C. Caranta and B. Vosman, "Development and Evaluation of Robust Molecular Markers Linked to Disease Resistance in Tomato for Distinctness, Uniformity and Stability Testing," Theoretical and Applied Genetics, Vol. 120, No. 3, 2010, pp. 655-664. doi:10.1007/s00122-009-1183-2

[16] I. Y. Choi, D. L. Hyten, L. K. Matukumalli, Q. Song, J. M. Chaky, C. V. Quigley, K. Chase, K. G. Lark, R. S. Reiter, M. Yoon, E. Hwang, S. Yi, N. D. Young, R. C. Shoemaker, C. P. van Tassell, J. E. Specht and P. B. Cregan, "A Soybean Transcript Map: Gene Distribution, Haplotype and Single Nucleotide Polymorphism Analysis," Genetics, Vol. 176, No. 1, May 2007, pp. 685-696. doi:10.1534/genetics.107.070821

[17] S. Giancola, H. I. McKhann, A. Berard, C. Camilleri, S. Durand, P. Libeau, F. Roux, X. Rebound, I. G. Gut and D. Brunel, "Utilization of Three High-Throughput SNP Genotyping Methods, the GOOD Assay, Amplifluor and Taqman, in Diploid and Polyploidy Plants," Theoretical and Applied Genetics, Vol. 112, No. 6, 2006, pp. 11151124. doi:10.1007/s00122-006-0213-6

[18] J. A. Labate and A. M. Baldo, "Tomato SNP Discovery by EST Mining and Resequencing," Molecular Breeding, Vol. 16, No. 4, November 2005, pp. 343-349. doi:10.1007/s11032-005-1911-5

[19] J. M. Jimenez-Gomez and J. N. Maloof, "Sequence Diversity in Three Tomato Species: Snps, Markers, and Molecular Evolution," BMC Plant Biology, Vol. 9, July 2009, p. 85. doi:10.1186/1471-2229-9-85

[20] J. A. Rafalski, "Application of Single Nucleotide Polymorphisms in Crop Genetics," Current Opinion in Plant Biology, Vol. 5, No. 2, April 2002, pp. 94-100. doi:10.1016/S1369-5266(02)00240-6

[21] A. Shi, R. Vierling, R. Grazzini, P. Chen, H. Caton and Y. Weng, "Development of Single Nucleotide Polymorphism Markers for Selection of Ve Gene of Tomato Verticillium Wilt Resistance," International Research Journal of Plant Science, Vol. 1, No. 2, August 2010, pp. 034-042.

[22] W. Yang, S. A. Miller, J. W. Scott, J. B. Jones and D. M. Francis, "Ming Tomato Genome Sequence Databases for Molecular Markers: Application to Bacterial Resistance and Marker Assisted Selection," Acta Hort (ISHS), Vol. 695, 2005, pp. 241-250.

[23] W. Yang, X. Bai, E. Kabelka, C. Eaton, S. Kamoun, E. van-der-Knaap and D. Francis, "Discovery of Single Nucleotide Polymorphisms in Lycopersicon Esculentum by Computer Aided Analysis of Expressed Sequence Tags," Molecular Breeding, Vol. 14, No. 1, 2004, pp. 21-34. doi:10.1023/B:MOLB.0000037992.03731.a5

[24] N. Acciarri, G. L. Rotino, G. Tamietti, D. Valentino, S. Voltattorni and E. Sabatini, "Molecular Markers for Ve1 and Ve2 Verticillium Resistance Genes from Italian Tomato Germplasm," Plant Breeding, Vol. 126, No. 6, December 2007, pp. 617-621. doi:10.1111/j.1439-0523.2007.01398.x

[25] J. J. Doyle and J. L. Doyle, "Isolation of Plant DNA from Fresh Tissue," Focus, Vol. 12, No. 1, 1990, pp. 13-15.

[26] P. J. Bradbury, A. Zhang, D. E. Kroon, T. C. Casstevens, Y. Ram-Doss and E. S. Buckler, "TASSEL Software for Association Mapping of Complex Traits in Diverse Samples," Bioinformatics, Vol. 23, No. 19, June 2007, pp. 2633-2635. doi:10.1093/bioinformatics/btm308 